\title{
EFFECT OF VEHICULAR POLLUTION ON CHLOROPHYLL CONTENT OF SOME ROAD SIDE PLANT IN NAGPUR
}

\author{
Jyoti R. Lilhare \\ P.G.T.D of Botany, RTMNU Campus Nagpur \\ lilhare.jyoti@gmail.com
}

Communicated : 17.12.19

Revision : 06.01.2020

Accepted : 24.01.2020

Published: 30.01.2020

\begin{abstract}
:
In the present study, one of the highly polluted areas was Nagpur city, the segment of road between Ravinagar and Futala was selected. This area consists of three signal and seven cross roads. Being National highway maximum vehicles pass through this road. In this area many plants are grown for beauty and many avenue trees are planted on road sides. Twenty plant species were selected for present study. Out of 20 plants 3 species are herbs, two species are tree species and 15 are shrubs. In the present study only chlorophyll content was calculated as a physiological parameter. The present study clearly establishes that the reduction in the level of of pigment due to air pollution except the Leucaenalati siliqua, Duranta erecta, Annona squamosa, Hibiscus rosa-sines is the content of pigment was same in the Psidium guajava and Nerium. Therefore, plant quickly responds to air pollutants and this is brought out by the modification of various fruits in them. Hence they can be utilized as biological indicators of air pollution. The present study on clearly establishes that the experimental sites chosen in this study is highly polluted.
\end{abstract}

Key words: - Vehicals, Chlorophyll pigments, road site pollution, ravinagar, futala.

\section{INTRODUCTION:}

Clean air can no longer be taken for granted. Today the air in most large Indian cities is severely polluted and this pollution has a tremendous impact on the health of the population. Industrialization, the growth in number of vehicles in urban areas and the burning of bio-fuels in rural households have lead to a rapid deterioration of indoor and outdoor air quality out of the 23 metro and Mega cities, Delhi is the most polluted followed by Mumbai, Calcutta, Bangalore,Chennai, Kanpur, Ahmadabad and Nagpur in India. They have severe air pollution problems with the average levels of suspended particulate matter levels much higher than the prescribed standards (Anonymous, 2001)

Clean air has so far been treated as an unlimited and free natural's resource. Only now as the health costs of polluted air are mounting, people are beginning to realize that clean air is valuable. The health impact of pollution is considerable. Premature deaths due to respiratory and cardio - vascular diseases like asthma and bronchitis have increased. According to a world bank study, in 1995 air pollution might have accounted for some 40,350 premature deaths and 19,805 thousand hospital admissions and 1200 million minor illnesses. In the last 4 years the number of premature deaths have increased by $28 \%$ and the number of sickness and hospital admissions by $30 \%$ Another study estimates that $4,10,000$ to $5,70,000$ women and young children die prematurely every year because of indoor air pollution caused by the burning of bio fuels in poor ventilated homes.

Urban air pollution is growing due to increasing power consumption industrialization and vehicle use. In urban centers studied by the central pollution control board, the suspended particular matter (SPM) is residential area exceeds critical limits set by the board in many cities. These studies revealed that it is not necessary that the larger cities are the more polluted ones Kanpur for instance has more particulate matter in the air than Mumbai, Calcutta or Delhi. 
In India surprisingly neither industries nor vehicles nor vehicles are the main source of air pollution. Burning of unprocessed cooling flues in homes causes the most pollution pollutants released indoors, due to their proximity to humans are for more dangerous than those released outdoors (Anonymous, 2001).

\section{Sources of air pollutants}

Air pollutants enter into the atmosphere by various natural and non-made activities such as dust, storm, volcanic, eruptions and industrial pollution etc. they may be present in any form viz. solid, liquid and gas (Raja, 1998) based on the mode of generation of pollutants, the sources are classified as
1) Natural
2) Manmade - sources.

\section{1) Natural Sources}

a)Forest Fires: - In the areas of tropical region or areas of high temperature throughout

b) Volcanic eruptions: - During the eruption of volcano, lava is produced along with release of minute solid particles, gases and radiations.

c) Dust Storms:- They are caused due to the movement of hot winds around the earth and are concentrated in certain places at particular time.

d) Pollen grains: - The pollutions is also caused by the production of large amount of pollens in the spring season. They are mainly responsible for causing allergy.

2)Man Made Source

a) Domestic Pollution: - The use of insecticides fuel in home for cooking purpose is the primary source of pollution in domestic area. b) Industrial Pollution:-The industrial activities are primarily responsible for the pollutions in India. The various industrial activities ranging from chemical industry, cement plants, paper mills to tanneries are major sources of pollution. The pollutants emitted also have vast difference in their properties. Trace element is released into the atmosphere along with gaseous pollutant like $\mathrm{So}_{2}$, oxides of nitrogen and particulate matter.

\section{MATERIAL AND METHODS:-}

\section{Study Area}

Nagpur is the largest city in Central India and the second capital of the state of Maharashtra. It is the fast growing metropolis and is the third most populous city in Maharashtra after Mumbai \& Pune $\&$ also one of the country's most industrialized cities. It is famous for Nagpur Orange and is known as the "Orange City". (Wikipedia).

Certain roads in Nagpur City are always seen with heavy vehicular traffic. The Ravinagar to Futada square always has shown a very heavy vehicular traffic. In these area many plant grow in roadside. These plants are constantly exposed to tremendous vehicular pollutions. At these segments consist of many important signal areas, lots of vehicles packed for road signals, the exposed the plants are morning to night constantly exposed to the exhaust smoke pollutants of vehicles.

\section{1) Selection of Site.}

Nagpur city is located in the Maharashtra State of Central India Business hub and increased industrialization in study area is affecting the enviourment adversely. On the other hand migrated man power contributed in the increase of population changing life style of corporate community and their effect on other population contamination the contamination of environment and therefore no. of pollution increase in the Nagpur.

Site for collecting polluted plants was chosen as Campus square signal because it is a National Highway and there is heavy traffic of two wheelers, 
three wheelers, four wheelers and multi axel heavy vehicles.

\section{2) Collection of Plants:}

For the present study, plants were collected in the month of Jan- Feb. The polluted plants were collected from the traffic signals whereas, unpolluted plants were collected from the RTMNU Campus, which are healthy and there is no effect of pollution. Collected plants were bought to the laboratory for the study. They were identified by using standard Floras. The following plants were chosen for the current study.

\begin{tabular}{|c|c|c|c|}
\hline No. & Species & Family & $\begin{array}{l}\text { Common } \\
\text { Name }\end{array}$ \\
\hline 1 & $\begin{array}{l}\text { Alstoniascholaris } \\
\text { (Linn.) R. Br. }\end{array}$ & $\begin{array}{l}\text { Apocynac } \\
\text { eae }\end{array}$ & Saptaparni \\
\hline 2 & $\begin{array}{l}\text { Alternentherases } \\
\text { silis (Linn.) R. } \\
\text { Br. Ex DC }\end{array}$ & $\begin{array}{l}\text { Amaranth } \\
\text { aceae }\end{array}$ & Kanchari \\
\hline 3 & $\begin{array}{l}\text { Annonasquamos } \\
\text { aLinn. }\end{array}$ & $\begin{array}{l}\text { Annonace } \\
\text { ae }\end{array}$ & Sitaphal \\
\hline 4 & $\begin{array}{l}\text { Bougainvillea } \\
\text { spectabilisWilld }\end{array}$ & $\begin{array}{l}\text { Nyctagina } \\
\text { ceae }\end{array}$ & Boganvel \\
\hline 5 & $\begin{array}{l}\text { Calotropisprocer } \\
\text { a(Ait.) R. Br. }\end{array}$ & $\begin{array}{l}\text { Asclepiad } \\
\text { aceae }\end{array}$ & Ak \\
\hline 6 & $\begin{array}{l}\text { Cassia fistula } \\
\text { Linn. }\end{array}$ & $\begin{array}{l}\text { Caesalpin } \\
\text { iaceae }\end{array}$ & Amaltash \\
\hline 7 & $\begin{array}{l}\text { Catharanthusros } \\
\text { eus(L.) G Don. }\end{array}$ & $\begin{array}{l}\text { Apocynac } \\
\text { eae }\end{array}$ & Sadafuli \\
\hline 8 & $\begin{array}{l}\text { Citrus } \\
\text { aurantifolia } \\
\text { (Christm.) } \\
\text { Swingle }\end{array}$ & Rutaceae & Nimbu \\
\hline 9 & $\begin{array}{l}\text { Durantaerecta } \\
\text { Linn. }\end{array}$ & $\begin{array}{l}\text { Verbenace } \\
\text { ae }\end{array}$ & $\begin{array}{l}\text { Golden } \\
\text { Duranta }\end{array}$ \\
\hline 10 & $\begin{array}{l}\text { Euphorbia } \\
\text { hirtaLinn. }\end{array}$ & $\begin{array}{l}\text { Euphorbi } \\
\text { ceae }\end{array}$ & Dudhi \\
\hline 11 & $\begin{array}{l}\text { FicusreligiosaLin } \\
\text { n. }\end{array}$ & Moraceae & Pipal \\
\hline 12 & $\begin{array}{l}\text { Hibiscus rosa- } \\
\text { sinesisLinn. }\end{array}$ & Malvaceae & Jaswand \\
\hline 13 & $\begin{array}{l}\text { Lantana camara } \\
\text { Linn }\end{array}$ & $\begin{array}{l}\text { Verbenace } \\
\text { ae }\end{array}$ & $\begin{array}{l}\text { Ghaneri, } \\
\text { Raimoni }\end{array}$ \\
\hline 14 & $\begin{array}{l}\text { Leucaenalatisiliq } \\
\text { ua (Linn.) Gillis }\end{array}$ & $\begin{array}{l}\text { Mimosace } \\
\text { ae }\end{array}$ & Subabhul \\
\hline 15 & $\begin{array}{l}\text { Neriumindicum } \\
\text { Mill }\end{array}$ & $\begin{array}{l}\text { Apocynac } \\
\text { eae }\end{array}$ & Kaner \\
\hline
\end{tabular}

\begin{tabular}{|c|c|c|c|}
\hline 16 & $\begin{array}{l}\text { Psidiumguajava } \\
\text { Linn. }\end{array}$ & Myrtaceae & Amrud \\
\hline 17 & $\begin{array}{l}\text { Tabernaemontan } \\
\text { acitrifolia Linn. }\end{array}$ & $\begin{array}{l}\text { Apocynac } \\
\text { eae }\end{array}$ & Swastik \\
\hline 18 & $\begin{array}{l}\text { Tabernaemontan } \\
\text { adivaricata } \\
\text { (Linn. ) R. Br. }\end{array}$ & $\begin{array}{l}\text { Apocynac } \\
\text { eae }\end{array}$ & Tagar \\
\hline 19 & $\begin{array}{l}\text { Tridaxprocumbe } \\
\text { ns Linn. }\end{array}$ & $\begin{array}{l}\text { Asteracea } \\
\text { e }\end{array}$ & Kambarmodi \\
\hline 20 & $\begin{array}{l}\text { Ziziphusmauritia } \\
\text { na Lam. }\end{array}$ & $\begin{array}{l}\text { Rhamnac } \\
\text { eae }\end{array}$ & Ber \\
\hline
\end{tabular}

\section{Estimation of Photosynthetic pigment}

Biochemical tests were carried out for the plants. For the estimation of the total chlorophyll the $80 \%$ acetone was prepared by dissolving $20 \mathrm{ml}$ distilled water in $80 \mathrm{ml}$ acetone. Fresh leaves were collected from the polluted and non-polluted sites. Fresh leaves were weighed and $1 \mathrm{~g}$ leaf was crushed into the mortar and pastel, $20 \mathrm{ml}$ of prepared acetone were taken into the mortar for crushing the leaves. The crushed leaves were homogenized with the help of muslin clothes and they were collected into the centrifuge tube and solution was centrifuged at $5000 \mathrm{rpm}$ for 5 minutes. Later, the supernatant were transferred into the $100 \mathrm{ml}$ volumetric flask and volume was making up to $100 \mathrm{ml}$ with the 80 $\%$ acetone. Then the pigment was read at 645, 652, \& $663 \mathrm{~nm}$ against acetone as a blank in a spectrophotometer. The chlorophyll content of the extract was estimated as per the formula. 


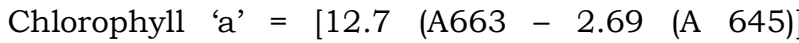
$\times \frac{v}{1000 \times W}$

Chlorophyll 'b' $=[28.9$ (A 645) -4.68 (A663) $]$

$\times \frac{v}{1000 \times W}$

Total chlorophyll $=[20.2(\mathrm{~A} 645)+8.02(\mathrm{~A} 663)] \times$

$\frac{v}{1000 \times N}$

Where, $A=$ absorbance

$\mathrm{V}=$ volume of the solution taken.

$\mathrm{A}=$ length of light path in the cell

$\mathrm{W}=$ fresh weight of sample in gram.

\section{RESULT AND DISCUSSION}

Air Pollutant, fly ash and dust emission have a profound impact on the concentration of different photosynthetic pigments. Polluted and dusted leaf surface is responsible for reduced photosynthetic and there by causing reduction in chlorophyll content. Variation in physiological characterstics of selected plants species exposed to the vehicular pollutants. In the present study, one of the highly polluted areas was Nagpur city, the segment of road between Ravinagar and Futala was selected. This area consists of three signal and seven cross roads. Being National highway maximum vehicles pass through this road. In this area many plants are grown for beauty and many avenue trees are planted on road sides. Twenty plant species were selected for present study. Out of 20 plants 3 species are herbs, two species are tree species and 15 are shrubs. For the study on effects on physiological parameters such as content of chlorophyll pigment have been studied.The present study clearly establishes that the reduction in the level of of pigment due to air pollution except the Leucaenalati siliqua, Duranta erecta, Annona squamosa, Hibiscus rosa-sinesis the content of pigment was same in the Psidium guajava and Nerium. Therefore, plant quickly responds to air pollutants and this is brought out by the modification of various fruits in them. Hence they can be utilized as biological indicators of air pollution. The present study on clearly establishes that the experimental sites chosen in this study is highly polluted.

\section{CONCLUSION}

The Increase in mobilization of human society has resulted in phenomenal rise in vehicular traffic on the mager road on aways. The vehicals discharge on appreciable amount of exhaust emission which consist of poisonous gases like carbonmonoxide, sulphor-di-oxide, oxides of nitrogen etc. $75 \%$ of Air pollution takes place throught exhaust gases from automobiles the emission from the vehicals cause adverse effect on plants, animal, soil and other environmental constituents . the present study deals with the effect of air pollution in perticulars, the vehicular pollution on plants. In the present study only chlorophyll content was calculated as a physiological parameter.The present study clearly establishes that the reduction in the level of of pigment due to air pollution except the Leucaenalati siliqua, Duranta erecta, Annona squamosa, Hibiscus rosa-sinesis the content of pigment was same in the Psidium guajava and Nerium.

Therefore, plant quickly responds to air pollutants and this is brought out by the modification of various fruits in them. Hence they can be utilized as biological indicators of air pollution. The present study on clearly establishes that the experimental sites chosen in this study is highly polluted.

\section{REFERENCES}

Agrawal, S.K. 1991. Pollution Ecology, Himanshu Publication, Udaipur.

Anonymous, 2001. Clean air Environmental Governance-4, Indira Gandhi Institute of Development Research, Mumbai.

Bansal, S.1988. Effect of certain atmosphere pollutants on fruits Diseases of Lycopersiconesculentum in Journal of Plant science. 
Benedict, H.M. and Bree, W.H. 1955. The use of weeds as a means of evaluating vegetation damage caused by air pollution, Proc. Third Natl. Air Pollutant. Symp. : 177-190 U.S.A.

ChandanBohra and Arvind Kumar 2004. Studies on air pollution due to Automobile exhaust in tribal dominated area of Jharkhand, India.

J. Curr Sci. Vol. 5(1):pp : 307-301

Dubey, P.S. and Pawar, K. 1985. Air pollution and plant responses Review of work done at Vikram Univ. Centre In: Perspectives in Env. Botony, Eds. D.N. rao, K.J.Ahmed, M.Yunis, S.N. Singh, Vol. 1 : 101-117, Print House, India, Lucknow.

Dubey, P.S., Trivedi L, Pawar ,. andShringi S.K. 1982.SO2 concentration and correlated chlophyll loss in tree species Sci. \& Cult. 48: 145-146.

Dubey, P.S. 1977. Herbicidal Pollution - Pollen damage due to herbicides, Environ Pollut. 13: 169-171.

Evans, W.C., 1996.Trease and Evan's Pharmacognosy, XIII ed. WB Saunders Ltd: UK.

Ghouse, A.K.M., Fareed A. Khan, M. Salauddin and Rasheed M.A. 1984. Indian J. Bot.7 (1): 84-86.

Hill, A.C andBenett, J.H., 1970.Inhabition of apparent photosynthesis by nitrogen oxides, Atomos . Environ. 4: 341 348.

Jafri S. Shrivastava K. and Ahmed K.J. 1979. Environmental pollution and epidermal Structure in Cuminisyzygium (L) Skeel : Indian J. Air Pollut, Control 2, pp $74-77$

Johansen, D.A., 1940. Plant Micro technique, me Graw Hill Book Co. Inc.: 15: 3 - 45
Katz, M., 1949. SO2 in the atmosphere and its relation to plant life. Ind. Eng. Chem. 42: $2450-2465$.

Kanti Srivastava, and Ahmad, K.J., 1982. Effect of air pollution on cuticular features of Croton SparuflorusMorong. New Botanist: IX: $27-29$.

Kulshreshtha , K. Yunus, M.,Dwivedi, A.K., and Ahmad, A.J., 1980. Effect of air pollution on the epidermal traits of JasminumsambacAit. New Botanist 7.

Me Cune, D.C., Weinstein, L.H.,Maclean, D.C. and Jacobson, K.S., 1967. The concept of hidden injury in plants. Science ....: $85-93$.

Pawar, K.,Dubey, P.S., and Mall, L.P., 1978. Air pollution damage in Azadirachtaindica $\mathrm{L}$, due to smoke of different origin. All India Symp., om Environmental Sciences and Human Welfare. Vikram University, Vjjain, India, Nov. 6 - 8: 9.

Pawar, K., 1982. Pollution studies in Nagda area due to Birla Industrial complex discharges. Ph. D. Thesis, Vikram University, Ujjain, India.

Bala, 2001. Effect of auto-exhaust pollution of the leaf micro morphology of Cassia siamea L.J. Indian bot SOC Vol 80 pp $35-38$.

Ramaswamy, V., 1991. Studies on the epidermal morphology and stomatal ontogeny in some members of myritales, Ph.D. Thesis, University of Madras: India.

Rao, C.S.G., Effects of air pollution in Indian Cities in Science and Culture.

Raju, B.S.N., "Fundamentals of Air Pollution", Oxford and IBH Publishing Company Private Limited, 1997.

Saxe, H., 1987. Stomata-dependant and stomata independent uptake of NOx , and effects on photosynthesis, respiration and transpiration of potted plants, in effects of atmospheric 
pollutants on forests, wetlands and agricultural ecosystem (ed), T.C. Hutchinson and K.M. Meema series Cr. Vol 16 pp.

Shevade, A., and Dubey, P.S., 1983. Herbicidal pollution: Low productivity and chlorophyll damage due to herbicide vapours, Indian J. Air pokkution control, 4(3): 1 - 3.

Singh, N., Yunus, M., Srivastava, K., Singh, S.M., Pandey, V., Misra, J. and Ahmed, K., 1995.Monitoring J. pollution road side of autoexhaust plants. Monitor. Assess. 34: 13 - 15.

Thomas, M.D., 1951.Gas damage to plants. Ann. Rev. Pl. Physiol, 2: 293 - 322.

Thompson, C.R.,Hensel, E.G.,Kat,s G,and Taylor, O.C., 1970. Effects of continuous exposure of navel organs to NO2 Atmos. Environ. 4: 344 - 355.

Tiwari, S., 1991. Studies of Air pollution Tolerance Indices of some planted trees in urban areas of Bhopal with reference to Eco-planning of Industrial areas. Ph.D. Thesis, Barkatullah University, Bhopal, India,.
Tiwari., and Bansal. Effect of MO2 pollution on Mimusopselengi Linn. In Asian Journal plant science Vol 5 (1) pp $83-87$.

Yunus, M., Ahmad, K.J., and Gale, 1979. Nature air pollutants and epidermal traits in Ricinuscommunis L. Environ, Pollut, 20: $189-198$.

Yunus, M., Kulshrestha, K., Divedi, A.K., and Ahmad, K.J., 1982. Leaf surface traits of Ipomea fistula Mart. Ex. Choisy as indicators of air pollution, New Botanist 9: $39-45$.

Yunus, M., and Ahmad, K.J., 1981. Changes in cuticular and epidermal feature of Calotropisprocera (Asclepiadaceae) due to air pollution, Kaliksam, Philipp. J. Biol 10: 275 - 282.

Yunus, M., and Ahmad, K.J., 1980. Effect of air pollution on Psidiumguajava L.; Indian K. Air Pollution control $362-66$.

Weinstein, L.H., and Me Cune, 1970. Effects of fluorides on vegetation. In S. N. Linzon (ED), Impact of Air pollution on vegetation: 81 - 86, Pittsburgh, Pennsylvania: Air pollution control association

\begin{tabular}{|c|c|c|c|c|c|c|c|}
\hline \multirow{3}{*}{ S.N } & \multirow{3}{*}{ Name Of Plant } & \multicolumn{4}{|c|}{ Pigment (mg/gm Fresh Weight) } & \multirow{2}{*}{\multicolumn{2}{|c|}{ Total Chlorophyll }} \\
\hline & & \multicolumn{2}{|c|}{ Chlorophyl A } & \multicolumn{2}{|c|}{ Chlorophyll B } & & \\
\hline & & Unpolluted & Polluted & Unpolluted & Polluted & $\begin{array}{l}\text { Unpolluted } \\
\qquad(\mathrm{A}+\mathrm{B})\end{array}$ & $\begin{array}{l}\text { Polluted } \\
(\mathrm{A}+\mathrm{B})\end{array}$ \\
\hline 1 & $\begin{array}{l}\text { Alstoniascholaris( } \\
\text { Linn.) R. Br. }\end{array}$ & 0.098 & 0.067 & 0.058 & 0.045 & 0.15 & 0.011 \\
\hline 2 & $\begin{array}{l}\text { Alternentherasess } \\
\text { ilis (Linn.) R. Br. } \\
\text { Ex DC }\end{array}$ & 0.029 & 0.049 & 0.034 & 0.012 & 0.049 & 0.029 \\
\hline 3 & $\begin{array}{l}\text { Annonasquamosa } \\
\text { Linn. }\end{array}$ & 0.055 & 0.044 & 0.066 & 0.091 & 0.085 & 0.103 \\
\hline 4 & $\begin{array}{l}\text { Bougainvillea } \\
\text { spectabilisWilld }\end{array}$ & 0.27 & 0.69 & 0.78 & 0.20 & 2.21 & 1.49 \\
\hline
\end{tabular}




\begin{tabular}{|c|c|c|c|c|c|c|c|}
\hline 5 & $\begin{array}{l}\text { Calotropisproceral } \\
\text { Ait.) R. Br. }\end{array}$ & 0.032 & 0.011 & 0.023 & 0.011 & 0.734 & 0.069 \\
\hline 6 & $\begin{array}{l}\text { Cassia fistula } \\
\text { Linn. }\end{array}$ & 0.023 & 0.012 & 0.014 & 0.010 & 0.212 & 0.016 \\
\hline 7 & $\begin{array}{l}\text { Catharanthusrose } \\
\text { us(L.) G Don. }\end{array}$ & 0.022 & 0.034 & 0.037 & 0.013 & 0.051 & 0.047 \\
\hline 8 & $\begin{array}{l}\text { Citrus aurantifolia } \\
\text { (Christm.) } \\
\text { Swingle }\end{array}$ & 0.019 & 0.021 & 0.065 & 0.058 & 0.085 & 0.058 \\
\hline 9 & $\begin{array}{l}\text { Durantaerecta } \\
\text { Linn. }\end{array}$ & 0.032 & 0.207 & 8.504 & 2.516 & 0.024 & 0.027 \\
\hline 10 & $\begin{array}{l}\text { Euphorbia } \\
\text { hirtaLinn. }\end{array}$ & 0.051 & 0.031 & 0.037 & 0.023 & 0.088 & 0.056 \\
\hline 11 & $\begin{array}{l}\text { FicusreligiosaLin } \\
\text { n. }\end{array}$ & 0.074 & 0.031 & 0.054 & 0.033 & 0.129 & 0.056 \\
\hline 12 & $\begin{array}{l}\text { Hibiscus rosa- } \\
\text { sinesisLinn. }\end{array}$ & 0.039 & 0.050 & 0.030 & 0.038 & 0.069 & 0.089 \\
\hline 13 & $\begin{array}{l}\text { Lantana camara } \\
\text { Linn }\end{array}$ & 0.044 & 0.011 & 0.041 & 0.019 & 0.085 & 0.024 \\
\hline 14 & $\begin{array}{l}\text { Leucaenalatisiliqu } \\
a \text { (Linn.) Gillis }\end{array}$ & 0.107 & 0.166 & 0.047 & 0.119 & 0.154 & 0.234 \\
\hline 15 & $\begin{array}{l}\text { Neriumindicum } \\
\text { Mill }\end{array}$ & 0.072 & 0.069 & 0.026 & 0.041 & 0.098 & 0.090 \\
\hline 16 & $\begin{array}{l}\text { Psidiumguajava } \\
\text { Linn. }\end{array}$ & 0.021 & 0.022 & 0.090 & 0.089 & 0.111 & 0.111 \\
\hline 17 & $\begin{array}{l}\text { Tabernaemontan } \\
\text { acitrifolia Linn. }\end{array}$ & 0.025 & 1.44 & 0.019 & 5.21 & 0.025 & 0.011 \\
\hline 18 & $\begin{array}{l}\text { Tabernaemontan } \\
\text { adivaricata (Linn. } \\
\text { ) R. Br. }\end{array}$ & 0.115 & 0.103 & 0.186 & 0.059 & 0.190 & 0.168 \\
\hline 19 & $\begin{array}{l}\text { Tridaxprocumben } \\
\text { s Linn. }\end{array}$ & 0.045 & 0.045 & 0.024 & 0.027 & 0.070 & 0.065 \\
\hline 20 & $\begin{array}{l}\text { Ziziphusmauritian } \\
\text { a Lam. }\end{array}$ & 1.12 & 0.021 & 8.12 & 0.021 & 2.17 & 0.043 \\
\hline
\end{tabular}

Chlorophyll A
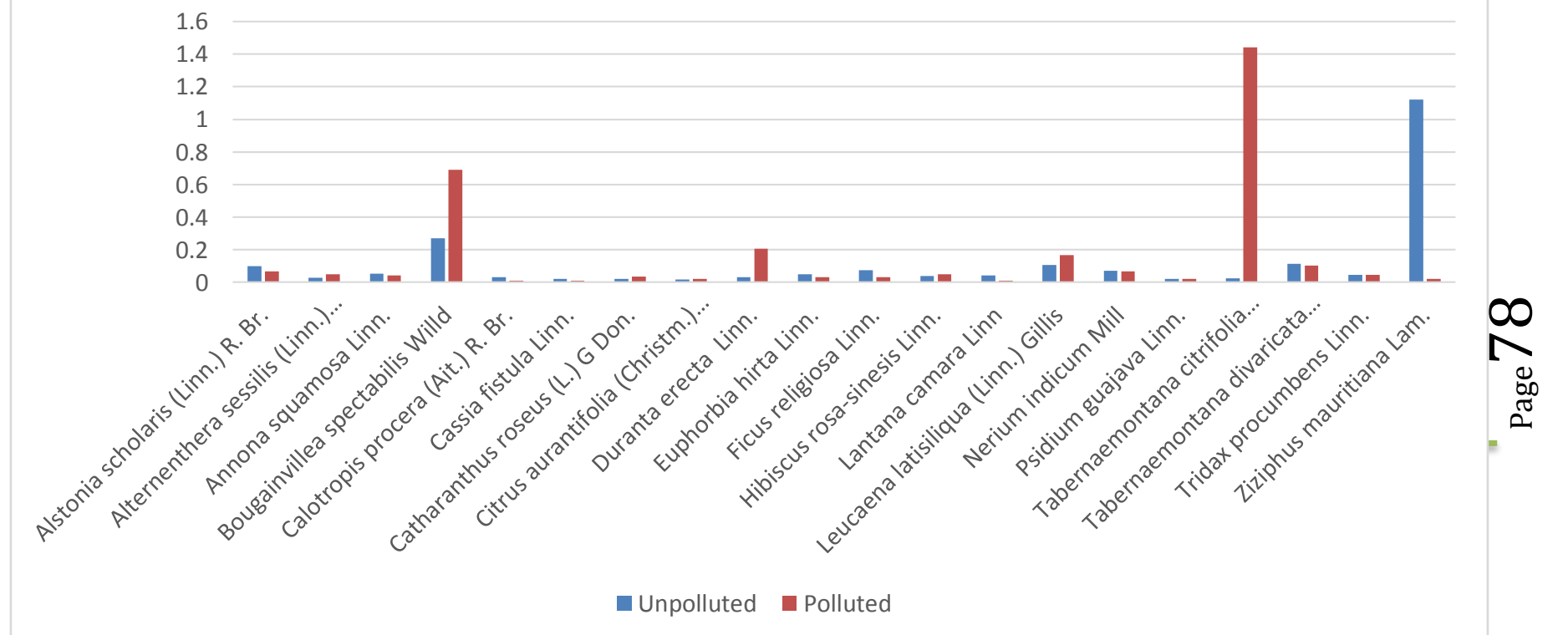
Figure 1 : Effect of vehicular Pollution on Chlorophyll "a" on plant species studies

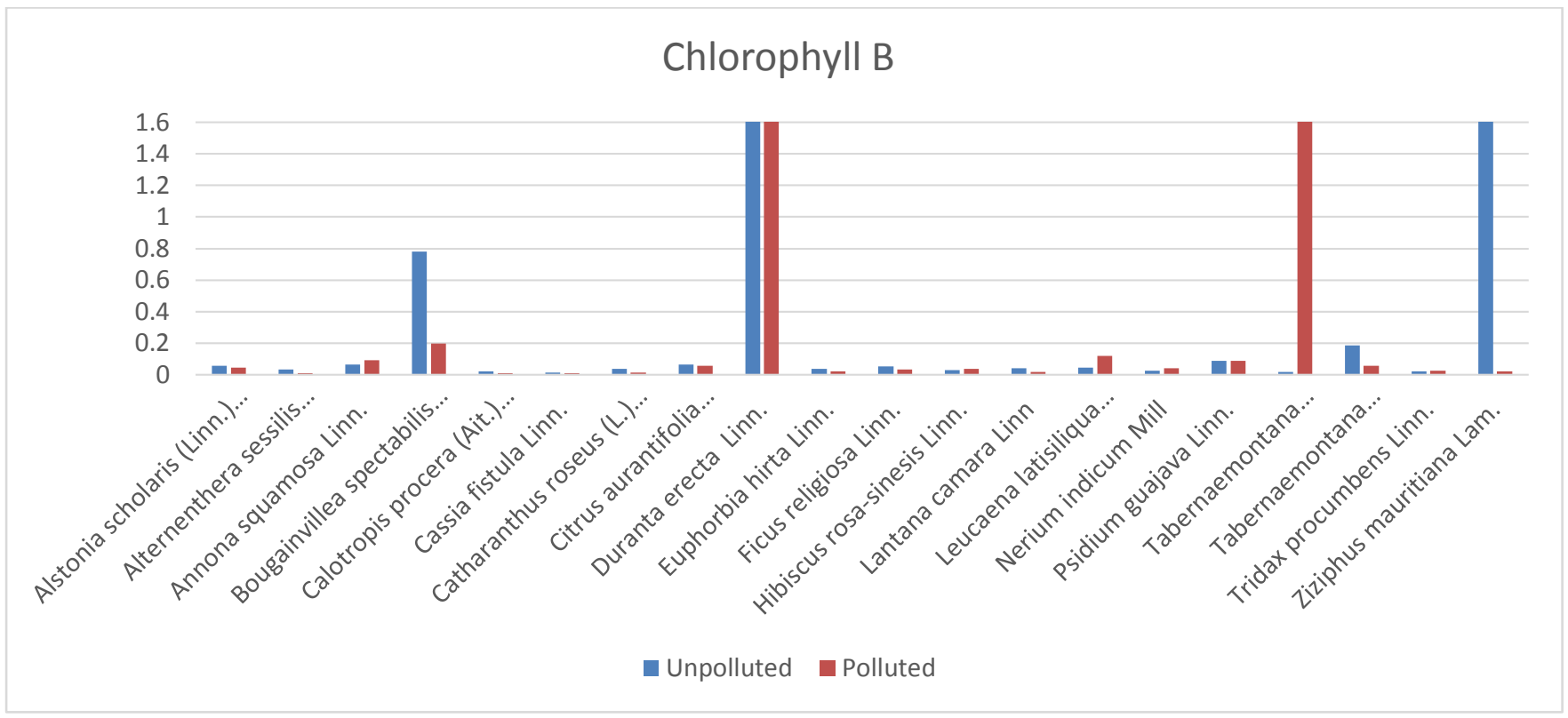

Figure 2 : Effect of vehicular Pollution on Chlorophyll "b" on plant species studies

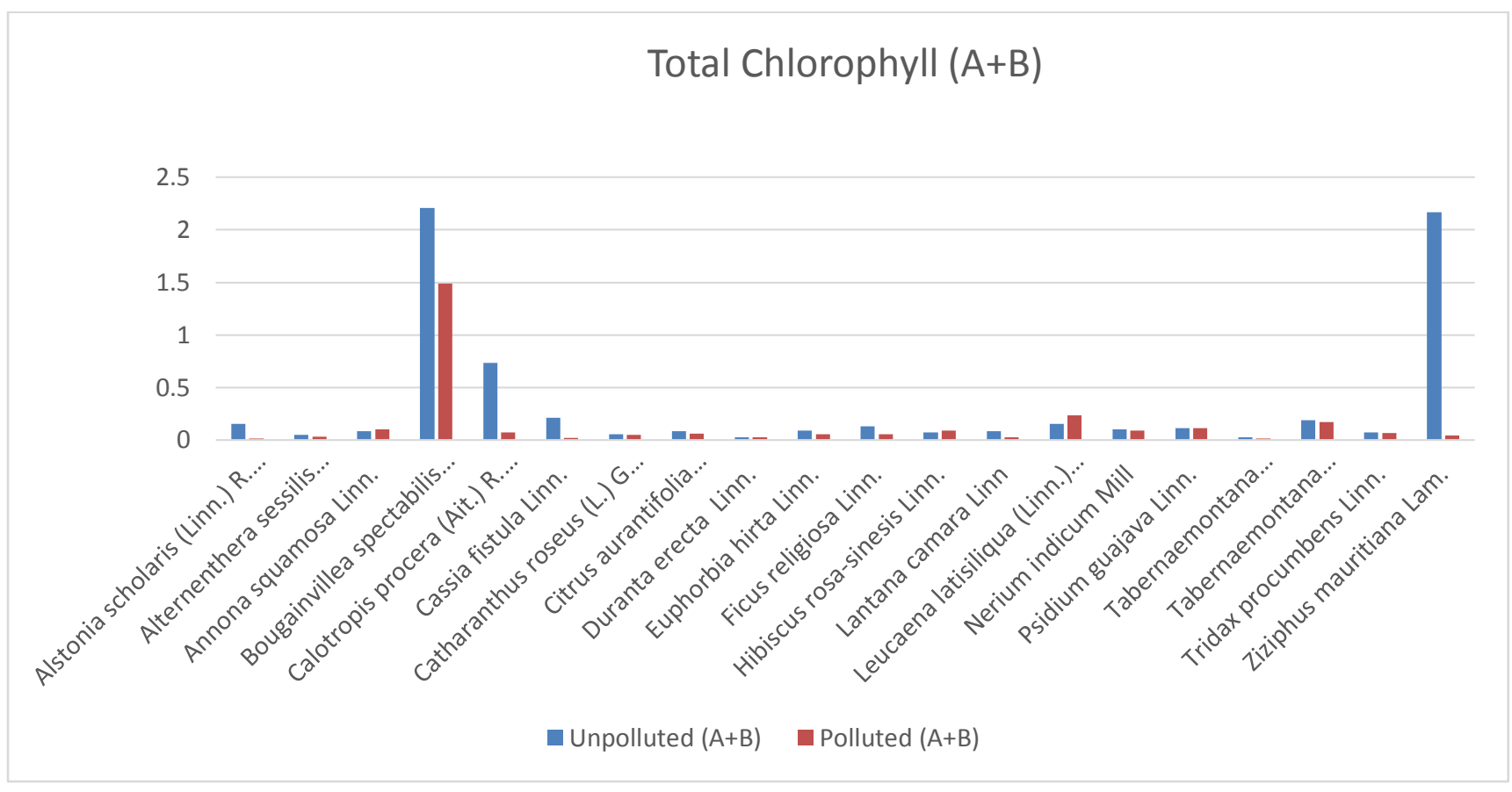

Figure 2 : Effect of vehicular Pollution on Total Chlorophyll "A+B" on plant species studies 